\title{
The Correlation between Bacteria and Parasite Patterns on Flies with Prevalence of Fly Vector-Borne Disease at the Market and the Landfill in Jember District, Indonesia
}

\author{
Riza Indira Fadillah Zam Zam ${ }^{1}$, Erma Sulistyaningsih ${ }^{2}$, Ancah Caesarina Novi Marchiant ${ }^{3}$ \\ ${ }^{1}$ Graduate Student, Magister Program ofPublic Health Education, University of Jember, East Java, Indonesia, \\ ${ }^{2}$ Department of Parasitology, Faculty of Medicine, University of Jember, Jember, East Java, Indonesia, ${ }^{3}$ Public \\ Health Lecturer,Faculty of Public Health Education, University of Jember, East Java, Indonesia
}

\begin{abstract}
Fly vector-borne diseases are the potential disease that can trigger an outbreak. The fly lives in a dirty place with poor sanitation, such as the market and the landfill. Some pathogens that can be transmitted by flies mechanically were bacteria such as Escherichia coli, Shigella, Salmonella, Vibrio cholera and parasites such as Balantidium coli, Entamoeba histolytica and Giardia lamblia. This study aimed to analyze the correlation between bacteria and parasite patterns on flies and the prevalence of fly vector-borne diseases. This research was conducted from May 2019 to March 2020. The flies samples were collected randomly at each research location, i.e., Tanjung Market and the Pakusari landfill. The bacteria and parasites identifications were carried out at the Microbiology and Parasitology Laboratory, Faculty of Medicine, University of Jember. The data of disease prevalence was collected in a cohort from the health centers around research locations. This study found three bacteria in market samples, 18 cases of fly vector-borne diseases and four bacteria in the landfill samples and 10 cases of fly vector-borne disease. The study indicated a significant correlation between bacteria and parasite patterns on flies with the prevalence of fly vector-borne diseases in the market, but no correlation in the landfill.
\end{abstract}

Keywords: Bacteria, Fly, Parasite, Vector-borne Disease.

\section{Introduction}

Fly vector-borne diseases are the potential disease that can trigger several extraordinary infectious diseases such as diarrhea, typhoid fever, dysentery and cholera. Flies are a type of vector that can carry germs on their bodies. They live close to humans and are often associated with sanitation problems. Environments with poor sanitation tend to attract flies as breeding place and

\section{Corresponding Author:}

\section{Dr. Rer. Biol. Hum. Dr. Erma Sulistyaningsih}

M.Si, Department of Parasitology, Faculty of Medicine, University of Jember, Jember, East Java, Indonesia

68121

Phone: +62331337877

e-mail:sulistyaningsih.fk@unej.ac.id feed them, they including the market and landfill. Those areas are suspected related to the incidence and spread of infectious diseases where pathogens originate from these places.

Fly can transmit the disease to humans mechanically by carrying microorganisms attached to their bodies to such media. Studies reported the pathogens that are transmitted mechanically by flies are Escherichia coli, Shigella, Salmonella, Vibrio cholera and parasites such as Balantidium coli, Entamoeba histolytica, Giardia lamblia. A species of fly, Musca domestica can transmit pathogens such as Campylobacter, E.coli, Salmonella $s p$., and Shigella $s p^{(16)}$. Previous studies on the detection of fly vector-borne diseases found the occurrence of diarrhea, dysentery, typhus and cholerain Jember District $2019^{(6)}$. The epidemiological study of vector-borne diseases showed the interconnection of three factors, i.e., human host, infectious agent (parasite, bacteria in 
the fly's body) and the environment where the place of the fly vector life. This study analyzed the role of flies in transmitting vector-borne diseases in Jember Regency, especially in an environment where the flies can breed and live easily, i.e., the market and the landfill.

\section{Method}

The research was conducted at the Tanjung market and the Pakusari landfill in May 2019 to March 2020. This research has received ethical clearance from the Ethical Committee of Health Research of Faculty of Dentistry, the University of Jember, with the reference number.632/UN25.8/KEPK/DL/2019. The sampling technique was carried out randomly at each location in November 2019. Researchers set a fly trap that was equipped with jackfruit bait with a strong aroma to catch flies. The caught flies were put into a sterile tube containing $\mathrm{NaCl} 30 \mathrm{ml}$ and marking each location and divided into two parts. The sample was analyzed at the Laboratory of Microbiology and Parasitology, Faculty of Medicine, the University of Jember. The bacterial identification was performed by selective media culture and several biochemical tests. The identification of parasites was made by microscopical examination. The prevalencedata of fly vector-borne diseases was provided in a cohort method from the health service around each research location. It was collected in the period of November-December 2019.

Research Findings: Bacterial identification of samples from the Tanjung Market found three types of bacterial patterns that are considered as Escherichia coli, Salmonella $s p$ and Shigella sp. Meanwhile, the samples from the Pakusari landfill showed four types of bacterial patterns, which were suspected as Escherichia coli, Salmonella sp, Shigella sp. and Vibrio cholera, as shown in Table 1 and Table 2.

Table 1. Bacterial Biochemical Tests on Flies from the Tanjung Market and the Pakusari landfill

\begin{tabular}{|c|c|c|c|c|c|c|c|}
\hline \multirow{2}{*}{ Sample Location } & \multirow{2}{*}{ Bacteria } & \multicolumn{6}{|c|}{ Biochemical Test } \\
\hline & & KIA & Indol & MIO & VP & MR & Citrate \\
\hline \multirow[t]{4}{*}{ Market } & E.coli & $\begin{array}{c}\mathrm{S}=\text { Alk } \\
\mathrm{B}=\text { Acid } \\
\mathrm{H}_{2} \mathrm{~S}=+ \\
\text { Gas }=-\end{array}$ & - & - & - & - & + \\
\hline & Salmonella & $\begin{array}{c}\mathrm{S}=\text { Alk } \\
\mathrm{B}=\text { Acid } \\
\mathrm{H}_{2} \mathrm{~S}=+ \\
\text { Gas }=+\end{array}$ & - & + & - & + & + \\
\hline & Shigella & $\begin{array}{c}\mathrm{S}=\text { Alk } \\
\mathrm{B}=\text { Acid } \\
\mathrm{H}_{2} \mathrm{~S}=- \\
\text { Gas }=-\end{array}$ & - & - & - & - & + \\
\hline & Vibrio cholerae & $\begin{array}{c}\mathrm{S}=\text { Alk } \\
\mathrm{B}=\text { Acid } \\
\mathrm{H}_{2} \mathrm{~S}=- \\
\text { Gas }=-\end{array}$ & - & + & + & - & + \\
\hline \multirow[t]{2}{*}{ Landfill } & E.coli & $\begin{array}{c}\mathrm{S}=\text { Alk } \\
\mathrm{B}=\text { Acid } \\
\mathrm{H}_{2} \mathrm{~S}=+ \\
\text { Gas }=-\end{array}$ & - & - & + & - & - \\
\hline & Salmonella & $\begin{array}{c}\mathrm{S}=\text { Alk } \\
\mathrm{B}=\text { Acid } \\
\mathrm{H}_{2} \mathrm{~S}=+ \\
\text { Gas }=+\end{array}$ & - & + & - & + & + \\
\hline
\end{tabular}




\begin{tabular}{|c|c|c|c|c|c|c|c|}
\hline \multirow{2}{*}{ Sample Location } & \multirow{2}{*}{ Bacteria } & \multicolumn{6}{|c|}{ Biochemical Test } \\
\hline & & KIA & Indol & MIO & VP & MR & Citrate \\
\hline & Shigella & $\begin{array}{c}\mathrm{S}=\text { Alk } \\
\mathrm{B}=\text { Acid } \\
\mathrm{H}_{2} \mathrm{~S}=- \\
\text { Gas }=-\end{array}$ & + & - & + & - & - \\
\hline & Vibrio cholerae & $\begin{array}{c}\mathrm{S}=\text { Alk } \\
\mathrm{B}=\text { Acid } \\
\mathrm{H}_{2} \mathrm{~S}=- \\
\mathrm{Gas}=-\end{array}$ & + & - & - & + & - \\
\hline
\end{tabular}

Explanation: $\mathrm{KIA}=$ Kligler Iron Agar; $\mathrm{MIO}=$ motility-indole-ornithin; $\mathrm{MR}=$ Methyl Red; VP = Voges Proskauer; $\mathrm{S}=$ slope; $\mathrm{B}=$ base; $\mathrm{Alk}=$ medium alkalis/bases (red); Acid = medium acidity (yellow); $\mathrm{H}_{2} \mathrm{~S}=$ hydrogen sulfide production.

Table 2. The Patterns of Bacteria and Parasites on Flies through Selective Media Culture Method and Microscopic Observations from Each Location

\begin{tabular}{|l|c|c|c|l|}
\hline \multirow{2}{*}{ Bacteria/Parasite } & \multirow{2}{*}{ Agar Media } & \multicolumn{2}{|c|}{ Location } & \multirow{2}{*}{ Description } \\
\cline { 3 - 5 } & & Market & Landfill & \\
\hline Esherichia coli & EMB & + & + & Selective media culture \\
\hline Shigella & SS & + & + & Selective media culture \\
\hline Salmonella & SS & + & + & Selective media culture \\
\hline Vibrio cholera & TCBS & - & - & Microscopic observation \\
\hline Entamoeba histolytica & & - & - & Microscopic observation \\
\hline Balantidium coli & & - & - & Microscopic observation \\
\hline Giardia lamblia & & - & &
\end{tabular}

Explanation: $\mathrm{EMB}=$ Eosin Methylene Blue $; \mathrm{SS}=$ Salmonella-Shigella $; \mathrm{TCBS}=$ Thiosulfate-Citrate-Bile-Sucrose

Table 3. showed that the prevalence of fly vector-borne disease around the market place was 18 cases, while from the landfill was 10 cases of fly vector-borne disease.

Table 3. The Prevalence of Fly vector-borne Diseasearound research Location During November December 2019

\begin{tabular}{|l|c|c|c|c|c|}
\hline \multirow{2}{*}{ Location } & \multicolumn{4}{|c|}{ Prevalence of Fly vector-borne Disease } & \multirow{2}{*}{ Total } \\
\cline { 2 - 6 } & Diarrhea & Typhoid & Dysentery & Cholera & 0 \\
\hline Market & 7 & 3 & 8 & 0 & 18 \\
\hline Landfill & 8 & 2 & 0 & 0 \\
\hline
\end{tabular}

Table 4. The Data Analysis on the Correlation of Bacterial and Parasite Patternsand the Prevalence of Fly Vector-borne diseases around research Location

\begin{tabular}{|l|c|c|}
\hline Location & Bacterial Pattern x Disease Prevalence & Statistical analysis \\
\hline Market & $3 * 79$ & $\begin{array}{c}\text { value }=21,000 \\
\text { Asymp. Sig }=0,013\end{array}$ \\
\hline Landfill & $4^{*} 165$ & $\begin{array}{c}\text { value }=14,000 \\
\text { Asymp. Sig }=0,082\end{array}$ \\
\hline
\end{tabular}

Explanation: value $=$ crosstab value Asymp. sig $=$ significance value 
This study found three patterns of bacteria but no parasite around the market place. The prevalence of fly vector-borne diseases around the market was 18 cases. The statistical analysisby using Chi-Square resulted value of 21,000 and a significance value of 0,013 , which was fewer than $\alpha(0,05)$, indicated its correlation, as shown in Table 4.Furthermore, this research found four patterns of bacteria and no parasite around the landfill. The prevalence of fly vector-borne diseasearound the landfill was 10 cases. The statistical testby Chi-Square showed a value of 14,000 and a significance value of 0,082 , which was higher than $\alpha(0,05)$, implicated no correlation.

\section{Discussion}

The method to analyze the pathogen can be performed by microscopic, selective media culture, as well as serological examination. In this research, a selective media culture examination was performed to identify bacteria. The Eosin Methylene Blue (EMB) identified Escherichia coli, theSalmonella-Shigella Agar (SSA) identified Salmonella $s p$ and Shigella $s p$ and the Thiosulfate-Citrate-Bile-Sucrose (TCBS) selected for Vibrio cholerae. For each media (EMB, SSA, TBCS), we conducted several biochemical tests such as Kligler Iron Agar (KIA), Indole test, Methyl Red (MR) test, Voges Proskauer (VP) test, MIO test and citrate test on each sample location. The KIA test on each agar media (EMB, SS, TBCS) measured the ability to produce slope (S), base (B), hydrogen sulfide $\left(\mathrm{H}_{2} \mathrm{~S}\right)$ and damp as the basis to identify a particular pattern of bacteria and its growth on each media ${ }^{(5)}$. For the identification of the parasite on Giardia lamblia, Entamoeba hitolystica and Balantidium coli was done through the microscopical examination by $1000 x$ magnification.

The sample from the market showed three types of bacteriai.e., Escherichia coli, Salmonella sp., and Shigella $s p$, but no parasites. The result is in accordance with the research done by Safitri ${ }^{(16)}$, which has found the dominant pattern of Escherichia coli, Salmonella sp., Shigella sp, and Staphylococcus bacteria within the fly around markets in Surabaya. Moreover, Escherichia coli bacteria was a group of Coliform bacteria that could stay in the human and cattle digestive tract. In a certain amount, Coliform bacteria could cause indigestion problems like diarrhea. According to Lima et $\mathrm{al}^{(12)}$, E.coli was a pathogen that can cause diarrhea and transmitted to the human through fly mechanically. Escherichia coli, Shigella spp., Salmonella spp. bacteria around the Tanjung Market were found and derived from contaminated foodstuff, fruit and vegetable because of dust and soil exposure.

This research found 18 cases of fly vector-borne disease from around the market. The occurrence of fly vector-borne disease was affected by several aspects as personal and environmental hygiene and environmental sanitation. The dirty environment turns any kind of pathogens to grow and attract fly. The average flight distance of some flies was about $6-9 \mathrm{~km}$ from the breeding place ${ }^{(5)}$. The population in that area has a high risk of infecting fly vector-borne diseases because bacteria can contaminate the foods and groceries. To keep the cleanliness of foodstuff, they needed to wash them with detergent to reduce the risk of pathogens such as E. coli, Shigella sp., Salmonella $s p$ to grow, which can be transmitted by the fly. The population who have a good hygiene practice would be prevented from the diseases. Furthermore, the individual with vulnerable conditions and had poor hygiene would be at risk of diseases.

The bacteria found on the flies around the landfill were Escherichia coli, Salmonella spp., Shigella sp. and Vibrio Cholera bacteria, but no parasites. This result was in line with the previous study by Yunita ${ }^{(18)}$, which has found the Salmonella sp, Providencia, Escherichia and Vibrio in the fly body around the Sukawintan landfill. The typhoid disease occursdue to Salmonella $s p$ infection in the intestinal tract ${ }^{(18)}$. Salmonella $s p$ in the landfill's flies was suspected because of the stack of organic and inorganic trash that produced leachate, which can be a suitable medium for the microorganism such as bacteria and parasite to grow. A previous study by Yunita ${ }^{(18)}$ has found fecal coliform bacteria such as Salmonella sp., Vibrio comma and Shigella in leachate. The pungent smell of leachate attracted flies to come close because theylike to pungent smell and dirty place ${ }^{(5)}$. The fly, which alighted in leachate or waste in landfills, directly carried pathogen bacteria on their bodies. The flies could fly up to $6-9 \mathrm{~km}^{(12)}$. The long flight distance of fly enabled them from the landfill to fly and alight in residential areas around the landfill. The fly which carried pathogen might contaminate food and water, which further can cause diseases such as thypoid fever if consumed by human.

The statistical analysis showed no significant correlation between bacteria and parasites patterns and the prevalence of fly vector-borne disease at the landfill. 
The reported vector-borne disease cases from the health care centers around the landfill in specific periods showed that the population around this landfill was avoided from dysentery and cholera. The occurrence of the disease is affected by the interaction between host, agent and environment. Cholera is caused by Vibrio cholerae, which is transmitted through contaminated foods and drinks by the fly as a vector. However, the dead Vibrio cholerae can not infect and cause disease on humans. However, the bacteria live at an optimum temperature of $18-37^{\circ} \mathrm{C}^{(10)}$. Vibrio cholerae was assumed to be dead before it reached the host, so it would not cause disease around the landfill area. The other presumption was hygiene practice that has been implemented by the population around the landfill. The hygiene practice and healthy life behavior could prevent the individual from many kinds of infectious and transmissible diseases like diarrhea, dysentery, cholera $^{(8)}$.

This research also detected Shigella $s p$. from the landfill sample, but there was no dysentery case reported. The dysentery is an infectious disease caused by Shigella $s p^{(4)}$, which can be transmitted by contaminated food and water ${ }^{(16)}$. When the Shigella sp. reaches the human digestive tract, the bacteria grow within colon epithelial cells, infect colonic mucosa and spread laterally into the surrounding cells. The infection occurs with a broad range of symptoms from asymptomatic, mild symptoms like watery diarrhea to severe symptoms like stomach cramps, nausea and vomiting, fever, anorexia and bloody feces with mucus ${ }^{(17)}$. Dysentery usually occurred in a dirty environment and poor sanitation area. The residential areas around the landfill have enough distance and space among houses, reducing the risk offly vectorborne disease transmission in the population. It was assumed that Shigella sp. bacteria, which transmitted by a fly vector, did not reach the host. Thus, the population around the landfill was avoided from dysentery.

According to Ismail ${ }^{(9)}$, the mechanism of disease transmission occurs in several ways, i.e., the way the agent leaves the reservoir, the transmission route to reach host and the port de entry to the host. The fly vector carried pathogen (agent) after leaving the location (reservoir) and went to the residential area would be the risk to cause disease. However, as long as the pathogen carried by fly did not reach to the host or get into the human body, the interaction of disease would not exist. The prevention of infection due to bacteria could be exerted by improving personal hygiene and maintenance of clean food and drink without contamination of pathogens carried by the fly ${ }^{(14)}$. The vector control was also an aspect that was put into a serious concern to prevent the occurrence and transmission of fly vectorborne disease ${ }^{(2)}$.

\section{Conclusion}

This research found three patterns of bacteria around the market and the landfill in Jember District during November-December 2019, i.e., Escherichia coli, Salmonella sp., and Shigella sp. The most prevalent cases around the location were diarrhea and typhoid. There was a correlation between the bacterial pattern on the fly and the fly vector-borne disease. The fly was the potential mechanical vector for several vector-borne diseases. We suggested collaborating with the local government or healthcare service with aimed to plan the fly vector control program and fly vector-borne disease prevention, particularly in the area with a high prevalence of the fly vector-borne disease.

\section{Conflict of Interest: None}

\section{Source of Funding: Self}

Ethical Clearance: This research has undergone ethical test in ethics commission of health research of Faculty of Dentistry, University of Jember in this following registration number 632/UN25.8/KEPK/ DL/2019.

\section{References}

1. Abbas, N., Azhar H., Khan A., dan Shad SA. Resistance of the house fly Musca domestica (Diptera: Muscidae) to lambda-cyhalothrin:mode of inheritance, relized heritability and cross-resistance to other insecticides. Journal NCBI. 2014;23(5): 791-801. doi:10.1007/s10646-014-1217-7

2. Adenusi, AA and Adewoga TO. Human intestinal parasites in non-biting synanthropic flies in Ogun State, Nigeria. Journal NCBI. 2013;11(3):181-9. doi:10.1016/j.tjmaid.2012.11.003. Epub 2013 Jan 3

3. Balla H, Usman Y, Muhammad A. The Role of house fly (Musca domestica) in mechanical transmission of intestinal parasites in Maiduguri metropolis, northeastern Nigeria. Journal Nat Sci Research. 2014;4: 60-66. P-ISSN2224-3186 E-ISSN 2225-0921

4. Bangkele, Elli Y., dkk. Efek Anti Bakteridari Ekstrak Lengkuas Putih (Alpinia galangal [L] Swartz) terhadap Shigella dysenteriae. Jurnal 
Kesehatan Tadulako. 2015;1(2). ISSN25020749http://jurnal.untad.ac.id/jurnal/index.php/ HealthyTadulako/index

5. Barreiro C, Albano H, Silva J, Teixeira P. Role of Flies as Vectors of Foodborne Pathogens in Rural Areas. Hindawi Publishing Corporation ISRN Microbiology. 2013;1-7. http://dx.doi. org/10.1155/2013/718780

6. Dinas Kesehatan Kabupaten Jember. Profil Kesehatan Kabupaten Jember 2017. Jember.

7. Ibrahim et al. Detection of Intestinal Parasites Transmitted Mechanically by House Flies (Musca domestica, Diptera: Muscidae) Infesting Slaughterhouse in Khartoum State, Sudan. International Journal of Tropical Diseases. 2018;1(1). doi.org/10.23937/ijtd-2017/1710011

8. Iqbal W, et al. Role of housefly (Musca domestica, Diptera; Muscidae) as a disease vector; A review. Journal of Entomologi and Zology Studies. 2014;2 (2): 159-163.ISSN 2320-7078

9. Ismail I,et al. The Diversity and Activity of Flies (Diptera: Cyclorrhapha) as Forensic Indicators at Outdoor and Indoor Rat Carccasses in Dramaga, Bogor. Jurnal Riset Veteriner Indonesia. 2018;2(2):70-78. P-ISSN:2614-0187. E-ISSN:2615-2835

10. Kharirie. Diagnosa Vibrio Cholerae dengan Metode Kultur dan Polimerase Chain Reaction (PCR) pada Sampel Sumber Air Minum. Jurnal Biotek Medisiana Indonesia. 2013;2(2). https://doi. org/10.22435/jbmi.v2i2.1634

11. Kohei Ogawa et al. Host Suitability of House Fly, Musca domestica (Diptera: Muscidae). Pupae Killed by High or Low Temperature Treatment for Parastoid, Spalangia endius (Hymenoptera:
Pteromalidae). The Scientific World Journal. 2012;2012(4).doi: 10.1100/2012/214907

12. Lima, M.s.C.S., Soares, M.R.A., Pederassi, J., Aguia, B.C.G. and Pereira, C.A.S. The Housefly Musca Domestica L. (Diptera: Muscidae) As a Paratenic Host In The City of Bom Jesus-Piau, Brazil. Comunicata Scientiae. 2014; 5(3): 349-55. https://doi.org/10.14295/cs.v5i3.461

13. Manandhar R and Gokhale S. Are houseflies still important vector gastrointestinal infections? Journal Bacteriol Parasitol. 2017;8(4): 318. DOI: 10.4172/2155-9597.1000318

14. Nurhayati. Gambaran Infeksi Protozoa Intestinal pada Anak Binaan Rumah Singgah Amanah Kota Padang. Majalah Kedokteran Andalas. 2010;34(1). https://doi.org/10.22338/mka.v34.i1.p60-69.2010

15. Safar, R. Parasitologi Kedokteran: Protozoologi, Entomologi dan Helmintologi. Edition I. Bandung: Yrama Widya. 2010. https://opac.perpusnas.go.id/ DetailOpac.aspx $? \mathrm{id}=707063$

16. Safitri, Venti., dkk. Identification of Bacteria on the Fly Exoskeleton in Some Markets in Surabaya. Journal of Parasite Science. 2017;1(1). http:// dx.doi.org/10.2473/jops.v1i1.16232

17. Yang JY., Lee SN., Chang SY., Ko HJ., Ryu S. and Kweon MN. A Mouse Model of Shigellosis by Intraperitoneal Infection. Seoul National University Seoul Korea.Journal Of Infectious Disease: Oxford Academic. 2013;209(5):203-15. https://doi. org/10.1093/infdis/jit399

18. Yunita, PP. Identifikasi Bakteri Pada Tubuh Lalat Rumah (Musca domestica Linn.) Di Tempat Pembuangan Akhir Sampah (TPA) dan Pasar. Jurnal Biota. 2018;4(1). https://doi.org/10.19109/ Biota.v4i1.1626 